\title{
p53-dependent apoptosis induced by proteasome inhibition in mammary epithelial cells
}

\author{
AP MacLaren ${ }^{\star, 1}$, RS Chapman ${ }^{1,3}$, AH Wyllie ${ }^{2}$ and \\ CJ Watson ${ }^{2}$ \\ ${ }^{1}$ Sir Alastair Currie CRC Laboratories, Molecular Medicine Centre, Western \\ General Hospital, Crewe Road, Edinburgh, EH2 4XU, UK \\ 2 Department of Pathology, University of Cambridge, Tennis Court Road, \\ Cambridge, CB2 1QP, UK \\ Current addresses: ${ }^{3} \mathrm{CRC}$ Institute for Cancer Studies, University of \\ Birmingham, Vincent Drive, Edgbaston, Birmingham, B15 2TT, UK \\ * Corresponding author: AP MacLaren, CRC Beatson Institute for Cancer \\ Research, Garscube Estate, Switchback Road, Bearsden, Glasgow G61 1BD, \\ UK. Tel: 0140330 3958; Fax: 0140942 6521; \\ E-mail: A.Maclaren@beatson.gla.ac.uk
}

Received 20.3.00; revised 18.9.00; accepted 24.10.00

Edited by BA Osborne

\begin{abstract}
We have examined the effects of inhibition of the $26 \mathrm{~S}$ proteasome in a murine mammary cell line, KIM-2 cells using the peptide aldehyde inhibitor MG132. These studies have demonstrated a clear requirement for proteasome function in cell viability. Induction of apoptosis was observed following MG132 treatment in KIM-2 cells and this death was shown to be dependent on the cell actively traversing the cell cycle. KIM-2 cells were generated using a temperature sensitive T-antigen (Tag) and studies at the permissive temperature $\left(33^{\circ} \mathrm{C}\right)$ have shown that a Tag binding protein was essential for this apoptotic response. Studies in two additional cell lines, $\mathrm{HC11}$, which is a mammary epithelial cell line carrying mutant p53 alleles and p53 null ES cells suggest that p53 is actively required for the apoptosis induced as a consequence of proteasome inhibition. These results suggest a pivotal role for the $26 \mathrm{~S}$ proteasome degradation pathway in progression through the cell cycle in proliferating cells. Cell Death and Differentiation (2001) 8, 210-218.
\end{abstract}

Keywords: KIM-2 mammary epithelial cells; p53; apoptosis; $26 \mathrm{~S}$ proteasome

Abbreviations: ALLM, Ac-Leucinyl-leucinyl-methional; E64, transepoxysuccinyl-L-leucylamido-3-methyl-butane ethyl ester; GF, growth factor; MG132, $\mathrm{Cb}_{2}$-leucinyl-leucinyl-leucinal; PMSF, phenylmethylsulphonyl fluoride

\section{Introduction}

The normal growth and metabolism of cells are dependent not only on the presence and activation of critical proteins at specific times but also on their timely removal, thus allowing an ordered chain of events, i.e. cell cycle progression. A key player in the degradation of proteins within the cell is the $26 \mathrm{~S}$ proteasome. The vast majority of intracellular degradation is mediated by the $26 \mathrm{~S}$ proteasome and it is involved in selective turnover of proteins under basal metabolic conditions. Cells are often required to switch from one cellular state to another in response to environmental signals or as part of regulated developmental pathways. Switches of this manner require the rapid dismantling of existing regulatory networks, which are often dependent on protein degradation. The process of selective degradation has two major advantages: it is fast, and it is irreversible, thereby ensuring no inappropriate reactivation. These features explain why selective degradation plays such a prime regulatory role in systems which rely on timing controls.

The $26 \mathrm{~S}$ proteasome complex is composed of a central 205 core which contains all the proteolytic activity of the complex, and a regulatory 195 cap complex. The core complex is composed of seven different $\alpha$ and $\beta$ subunits, which form four rings each containing all seven subunits. The 19S cap complex is composed of 15 different subunits ranging in size from 25 to $110 \mathrm{kDa}$. In association with the $20 \mathrm{~S}$ proteasome, the 19S cap complex confers an ATP dependence on protein degradation. Within the cap there are six $\mathrm{Mg}^{2+}$-dependent ATPases which are thought to function in the unfolding and transportation of the substrate protein towards the proteolytic sites within the inner channel of the 205 core. ${ }^{1}$ Proteins which are targeted for degradation are identified by attachment of a polyubiquitin tail, a process itself catalysed by a complex cascade of enzymes. Of the non-ATPase subunits in the cap complex, one protein (S5) has been shown to bind multi-ubiquitin chains and therefore appears to be responsible for recognition of the ubiquitinated substrate protein by this complex. ${ }^{2}$ A number of natural substrates of this pathway exist. These range from proteins as diverse as the transcription factor $\mathrm{NF} \kappa \mathrm{B}$ to the cyclins. Degradation of the $\mathrm{NF} \kappa \mathrm{B}$ inhibitor, $\mathrm{I}_{\kappa} \mathrm{B} \alpha$ allows activation of this transcription factor by relieving cytoplasmic tethering, whereas degradation of the $B$ type cyclins permits cells to exit mitosis and divide. ${ }^{3,4}$

By its very nature the $26 \mathrm{~S}$ proteasome could be expected to play a pivotal role in the control of normal cell processes of proliferation, differentiation and apoptosis. Apoptosis is the process whereby a cell undergoes a genetic program resulting in self destruction. ${ }^{5}$ It is a widespread phenomenon that underlies both normal development and pathogenesis. The molecular events controlling this process at present remain unclear, but more recently the proteolytic events occurring during the apoptotic cascade have become the prime focus of this research field. It has become apparent that the activation of 
proteolytic enzymes is paramount to the apoptotic process. $^{6}$ The major proteases involved in apoptosis are a family of cysteine proteases called Caspases. These proteins are activated by proteolytic cleavage of proenzymes and thus trigger a multi-enzyme cascade that drives apoptotic events. Any role that the proteasome may play during an apoptotic cascade is currently unclear.

The mammary gland is a unique model system to study as it has the ability to undergo successive rounds of proliferation, differentiation and apoptosis. It is therefore one of the few tissues in which questions relating to all three of these processes can be addressed. In this study the model of mammary development used was KIM-2 cells. $^{7}$ Using a differential display approach we had previously observed upregulation of some proteasome components during proliferation of the gland and for these reasons we decided to examine the consequences of proteasome disruption within an actively dividing cell. Using the KIM-2 mammary epithelial cell line we have demonstrated an absolute requirement for a functional 26Sdegradation pathway during proliferation. Inhibition of this pathway was observed to induce apoptosis that was dependent on the presence of an SV40 Tag binding protein. Studies with p53null ES cells demonstrated that p53 was essential for cell death induced by proteasome inhibition. This study thus extends our knowledge of the essential role the proteasome plays in maintaining a healthy cellular environment.

\section{Results}

\section{Proteasome inhibition induces apoptosis}

The KIM-2 mammary epithelial cell line was used in this study. As anticipated molecular markers of mammary differentiation were identified in KIM-2 cells cultured under appropriate conditions. ${ }^{7}$ Thus these cells represent a good in vitro model in which to study mammary epithelial development. The peptide aldehyde inhibitor of the proteasome, MG132 selectively inhibits the $26 \mathrm{~S}$ proteasome. ${ }^{8}$ To investigate the role of the proteasome in apoptosis, we examined the effect of

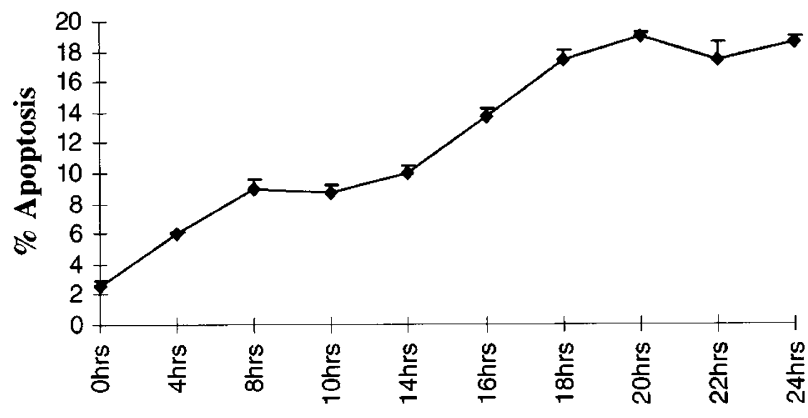

Duration of Treatment

Figure 1 Annexin $\mathrm{V}$ time-course on $\mathrm{KIM}-2$ cells. Cells were treated with MG132 over a $24 \mathrm{~h}$ period. Samples were harvested and an Annexin V assay performed. The results shown are the mean of three experiments \pm S.E.M., and are expressed as the percentage of Annexin $V$ positive cells
MG132 treatment on KIM-2 cells. Figure 1 shows results from KIM-2 cells treated with MG132, and harvested over $24 \mathrm{~h}$. These results show that apoptotic cells can be observed within $4 \mathrm{~h}$ of MG132 treatment. The level of apoptosis increases until $18-20 \mathrm{~h}$ where it reaches a maximum of $20 \%$. This is seen to correlate with a cell division time of $24 \mathrm{~h}$ in this cell line. We then examined the effects of a range of protease inhibitors on $\mathrm{KIM}-2$ cells to determine if the apoptosis observed was specific to proteasome inhibition. The results shown in Table 1 were determined from morphological analysis of acridine orange stained cells. Apoptosis was identified by the presence of membrane blebbing, cytoplasmic shrinkage, and nuclear fragmentation. The cysteine/serine protease inhibitor, Leupeptin, the aspartic protease inhibitor, Pepstatin, and the serine protease inhibitor, PMSF did not induce apoptotic cell death at high concentrations over a $24 \mathrm{~h}$ period..$^{9-11}$ Similarly, the lysosomal cathepsin inhibitor, E64 did not induce apoptosis in KIM-2 mammary epithelial cells. In contrast to this, the calpain II inhibitor ALLM induced a low level of apoptosis $(13 \%)$ at a high concentration $(100 \mu \mathrm{M})$ over the course of the experiment. Two $\mu \mathrm{M}$ of MG132 induced $>25 \%$ apoptosis over an identical time period. ALLM is well documented to cross-react with the proteasome as well as calpains. ${ }^{8}$ E64 has cross-reactive inhibitory activity on calpains but did not induce apoptosis, therefore it seems highly likely that the death observed with high concentrations of ALLM treatment is due to its inhibitory activity on the $26 \mathrm{~S}$ proteasome rather than the inhibition of calpains. In addition a second $26 \mathrm{~S}$ proteasome inhibitor, Lactacystin was used and yielded very similar results to those observed with MG132, further evidence that the initiation of apoptosis was specific to the blockage of protein degradation by the $26 \mathrm{~S}$ proteasome.

In KIM-2 cells we have shown that proteasome blockage induces an apoptotic response. In order to address whether proteasome inhibition could also play a protective role in

Table 1 Effect of a range of protease inhibitors on KIM-2 mammary epithelial cells

\begin{tabular}{lc}
\hline Treatment & \% Apoptotic cells \\
\hline Control & 0.64 \\
$3 \%$ FCS & 18.7 \\
$500 \mu \mathrm{M}$ PMSF & 0.8 \\
$500 \mu \mathrm{M}$ Leupeptin & 0.95 \\
$500 \mu \mathrm{M}$ Pepstatin A & 1.8 \\
$500 \mu \mathrm{M}$ E64d & 1.6 \\
$10 \mu \mathrm{M}$ Calpain II inhibitor & 2.3 \\
$25 \mu \mathrm{M}$ Calpain II inhibitor & 2.4 \\
$50 \mu \mathrm{M}$ Calpain II inhibitor & 5.7 \\
$100 \mu \mathrm{M}$ Calpain II inhibitor & 13.7 \\
$0.75 \mu \mathrm{M}$ MG132 & 2.5 \\
$1 \mu \mathrm{M}$ MG132 & 5.3 \\
$1.5 \mu \mathrm{M}$ MG132 & 16.1 \\
$2 \mu \mathrm{M}$ MG132 & 29.3 \\
$0.1 \mu \mathrm{M}$ Lactacystin & 2.8 \\
$1 \mu \mathrm{M}$ Lactacystin & 24.5 \\
$10 \mu \mathrm{M}$ Lactacystin & 37.8 \\
\hline
\end{tabular}

The protease inhibitors PMSF, Leupeptin, Pepstatin A, E64d, Calpain II Inhibitor, MG132 and Lactacystin were added to media at various concentrations for $24 \mathrm{~h}$. Cells were harvested and fixed for staining with acridine orange. The percentage death is shown as the mean of three independent experiments 
mammary epithelial cells, KIM-2 cells were serum and growth factor (GF) starved to induce an apoptotic response. These cells were also treated with two concentrations of MG132 and the level of apoptosis analyzed. Annexin V staining determined that MG132 could not protect from apoptosis induced by GF withdrawal (Figure 2). The effects on death observed were seen to be additive. These experiments suggested that the proteasome was not involved in degrading and/or processing a protein that is essential for driving apoptosis induced by growth factor and serum starvation.

\section{MG132 treatment induces apoptosis in a cell cycle dependent manner}

To address the question of whether differences in cell cycle status might alter sensitivity to proteasome inhibition KIM-2 cells at different stages of confluency were treated with MG132 and death assessed morphologically by acridine orange staining. These results showed that in cells treated $4 \mathrm{~h}$ following passaging, MG132 addition for the following $24 \mathrm{~h}$ induced $50 \%$ apoptosis (Figure 3a). The level of death observed decreased as the cells became more confluent suggesting that the apoptosis induced had a dependency on the cells being within the cell cycle. KIM-2 cells reach confluency by $72 \mathrm{~h}$ which corresponds to the rate of apoptosis reaching a baseline level of approximately $20 \%$. This was shown not to be the case for serum starved cells. A $10-15 \%$ death rate was observed with this death stimulus regardless of the confluency state of the cells.

To address whether KIM-2 cells were dying from a specific point in the cell cycle, we synchronised KIM-2 cells in $\mathrm{G} 1$ with the anti-metabolite Hydroxyurea and in G2/M with Nocodazole, a spindle poison. Cells were blocked for $24 \mathrm{~h}$ (equivalent to approximately one cell cycle) and then the drug was removed and replaced with either maintenance media (MM) or MM containing MG132. Cells were harvested and stained with annexin $V$ for apoptosis analysis or fixed and stained with Propidium lodide (PI) for cell cycle analysis. Results for cells blocked in G1/S phase showed that apoptosis was detectable within $2 \mathrm{~h}$ of MG132 treatment, and this increased dramatically by $4 \mathrm{~h}$

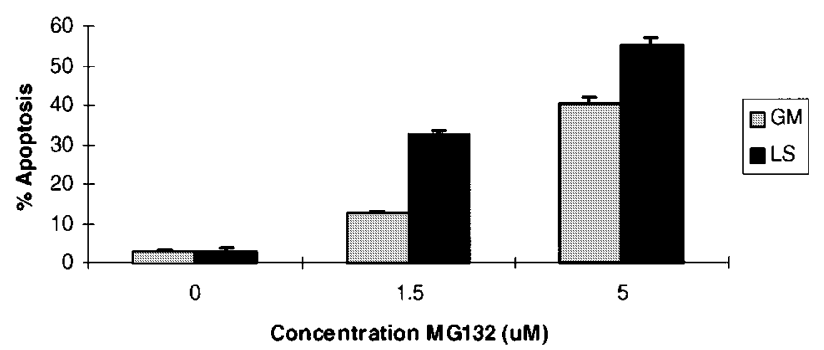

Figure 2 Can proteasome inhibition protect from apoptosis? Confluent KIM-2 cells were treated with either Growth media (GM), low serum media (LS) or with two different concentrations of MG132 (1.5 and $5 \mu \mathrm{M})$ for $24 \mathrm{~h}$ alone to induce apoptosis. Test samples were treated with $3 \%$ FCS and simultaneously with either concentration of MG132 to determine if proteasome inhibition could protect from apoptosis induced by growth factor and serum withdrawal. Samples were harvested at $24 \mathrm{~h}$ and an Annexin V assay was performed. Results shown are expressed as means \pm S.E.M. and thereafter increased slowly. In contrast to this, cells which had been blocked in G2/M showed a substantial increase in annexin $\mathrm{V}$ staining only at $12-16 \mathrm{~h}$ after treatment with MG132 (Figure 3b). Analysis of the cell cycle kinetics demonstrated that in cells released from G1 synchronisation, MG132 treatment caused an accumulation of cells in the G1/S-phase of the cell cycle (Table 2). $\mathrm{KIM}-2$ cells synchronised in $\mathrm{G} 2$ prior to proteasome inhibition appeared to progress through G2/M but at a much slower rate than cells which were released from the block into maintenance media. The MG132 treated cells did not begin to accumulate in G1/S-phase until $10-12 \mathrm{~h}$

(a)

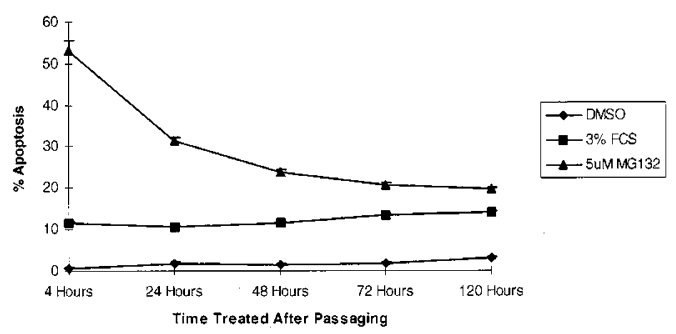

(b)

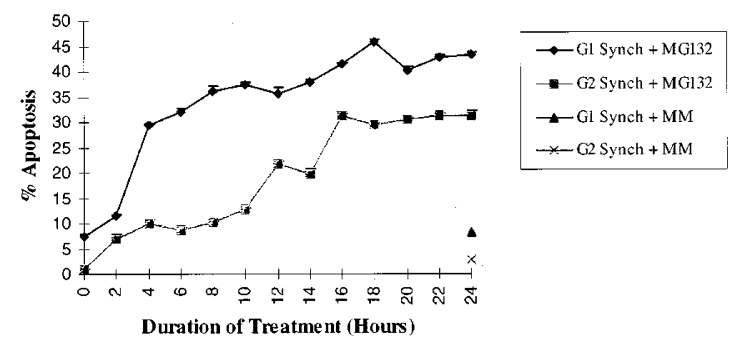

(c)

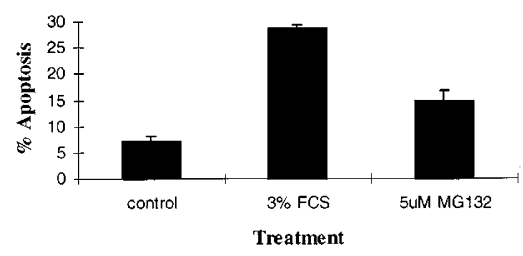

Figure 3 (a) Apoptosis analysis in a proliferating cell population. KIM-2 cells were passaged and treated with either DMSO, or serum and growth factor deprived, or cultured in the presence of $5 \mu \mathrm{M} \mathrm{MG132}$, at $4,24,48,72$, and $120 \mathrm{~h}$ after passaging. Cells were treated for a further $24 \mathrm{~h}$ and an Annexin V assay performed. Results are shown as the percentage of Annexin $\mathrm{V}$ positive cells, as the mean of three experiments \pm S.E.M. Cells were confluent at the $72 \mathrm{~h}$ stage. (b) Apoptosis induction as a consequence of proteasome inhibition following cell cycle synchronisation in KIM-2 cells. KIM-2 cells were passaged and allowed to grow for $24 \mathrm{~h}$. Cells were subsequently blocked in G1/S-phase or at the G2/M boundary with Hydroxyurea $(1 \mathrm{mM})$ or Nocodazole $(50 \mathrm{ng} / \mathrm{ml})$ respectively for $24 \mathrm{~h}$ (approximate cell division time). Following synchronisation cells were washed to remove the blocking drugs and then treated with either maintenance media (MM) or MM supplemented with $5 \mu \mathrm{M}$ MG132 over a $24 \mathrm{~h}$ period. Cells were harvested and an Annexin $\mathrm{V}$ assay performed. Results shown are expressed as the percentage of Annexin $\mathrm{V}$ positive cells. The data is the mean of three experiments \pm S.E.M. (c) Effect of proteasome inhibition on differentiated KIM-2 cells. KIM-2 cells differentiated for 12 days in the presence of prolactin and dexamethasone were treated with either $3 \%$ FCS or $5 \mu \mathrm{M} \mathrm{MG132}$ for $24 \mathrm{~h}$. Cells were harvested and stained with annexin V. Results are expressed as the mean of three experiments \pm S.E.M. 
Table 2 Induction of cell cycle arrest following proteasome inhibition in KIM-2 cells

\begin{tabular}{|c|c|c|c|c|c|c|c|c|}
\hline \multirow[b]{3}{*}{ rastr } & \multicolumn{4}{|c|}{ Hydroxyurea + MM } & \multicolumn{4}{|c|}{ Hydroxyurea + MG132 } \\
\hline & Pre-G1 & G1 & $\mathbf{s}$ & G2/M & Pre-G1 & G1 & $\mathbf{S}$ & G2/n \\
\hline & \multicolumn{4}{|c|}{ ( \pm S.E.M.) } & \multicolumn{4}{|c|}{ ( \pm S.E.M.) } \\
\hline $\mathrm{Hou}$ & $\begin{array}{c}13 \\
(0.3)\end{array}$ & $\begin{array}{l}67.9 \\
(1.3)\end{array}$ & $\begin{array}{c}14 \\
(0.2)\end{array}$ & $\begin{array}{c}8 \\
(0.4)\end{array}$ & $\begin{array}{c}6 \\
(0.4)\end{array}$ & $\begin{array}{c}70 \\
(1.7)\end{array}$ & $\begin{array}{c}10 \\
(0.5)\end{array}$ & $\begin{array}{c}11 \\
(0.3)\end{array}$ \\
\hline $2 \mathrm{H}$ & $\begin{array}{c}14 \\
(0.4)\end{array}$ & $\begin{array}{c}35 \\
(0.6)\end{array}$ & $\begin{array}{c}36 \\
(0.8)\end{array}$ & $\begin{array}{c}10 \\
(0.6)\end{array}$ & $\begin{array}{c}29 \\
(0.8)\end{array}$ & $\begin{array}{c}34 \\
(0.9)\end{array}$ & $\begin{array}{c}22 \\
(0.2)\end{array}$ & $\begin{array}{c}9 \\
(0.3)\end{array}$ \\
\hline \multirow[t]{3}{*}{24 Hours } & $\begin{array}{c}21 \\
(0.5)\end{array}$ & $\begin{array}{c}51 \\
(1.3)\end{array}$ & $\begin{array}{c}18 \\
(0.3)\end{array}$ & $\begin{array}{c}10 \\
(0.2)\end{array}$ & $\begin{array}{c}41 \\
(1.8)\end{array}$ & $\begin{array}{c}24 \\
(0.7)\end{array}$ & $\begin{array}{c}26 \\
(0.5)\end{array}$ & $\begin{array}{c}2 \\
(0.1)\end{array}$ \\
\hline & \multicolumn{4}{|c|}{ Nocodazole + MM } & \multicolumn{4}{|c|}{ Nocodazole + MG132 } \\
\hline & Pre-G1 & G1 & S & G2/M & Pre-G1 & G1 & S & G2/I \\
\hline Treatment & \multicolumn{4}{|c|}{ ( \pm S.E.M.) } & \multicolumn{4}{|c|}{ ( \pm S.E.M.) } \\
\hline Hours & $\begin{array}{c}8 \\
(0.1)\end{array}$ & $\begin{array}{c}15 \\
(0.3)\end{array}$ & $\begin{array}{c}12 \\
(0.3)\end{array}$ & $\begin{array}{c}65 \\
(1.6)\end{array}$ & $\begin{array}{c}2 \\
(0.2)\end{array}$ & $\begin{array}{c}6 \\
(0.7)\end{array}$ & $\begin{array}{c}7 \\
(0.6)\end{array}$ & $\begin{array}{c}74 \\
(2.1)\end{array}$ \\
\hline 12 Hours & $\begin{array}{c}8 \\
(0.2)\end{array}$ & $\begin{array}{c}51 \\
(0.3)\end{array}$ & $\begin{array}{c}15 \\
(0.1)\end{array}$ & $\begin{array}{c}20 \\
(0.2)\end{array}$ & $\begin{array}{c}11 \\
(0.5)\end{array}$ & $\begin{array}{c}18 \\
(0.8)\end{array}$ & $\begin{array}{c}12 \\
(1.2)\end{array}$ & $\begin{array}{c}45 \\
(0.9)\end{array}$ \\
\hline $4 \mathrm{H}$ & $\begin{array}{c}15 \\
(0.3)\end{array}$ & $\begin{array}{c}48 \\
(0.4)\end{array}$ & $\begin{array}{c}14 \\
(0.5)\end{array}$ & $\begin{array}{c}14 \\
(0.2)\end{array}$ & $\begin{array}{c}28 \\
(0.8)\end{array}$ & $\begin{array}{c}24 \\
(0.5)\end{array}$ & $\begin{array}{c}13 \\
(1.5)\end{array}$ & $\begin{array}{c}27 \\
(0.6)\end{array}$ \\
\hline
\end{tabular}

KIM-2 cells were treated for $24 \mathrm{~h}$ with either $1 \mathrm{mM}$ Hydroxyurea or $50 \mathrm{ng} / \mathrm{ml}$ Nocodazole $24 \mathrm{~h}$ following passaging. Cells were subsequently washed to remove the blocking drugs and then treated with either maintenance media alone (MM) or MM supplemented with $5 \mu \mathrm{M}$ MG132 over a $24 \mathrm{~h}$ time period. Cells were harvested and stained with Propidium lodide for cell cycle analysis. The flow data shown describes the 0,12 and $24 \mathrm{~h}$ treatments

following the onset of treatment. This corresponds to the onset of apoptosis in these cells. Taking the cell cycle and apoptosis results together it would appear that the $26 \mathrm{~S}$ proteasome is implicated in functioning during mitosis as MG132-treated KIM-2 cells were less efficient at traversing this stage of the cell cycle than control cells. These results also detailed an absolute requirement for proteasome function at the G1/-S phase of the cell cycle as the cells appeared to arrest and undergo apoptosis either during or following this stage in the cycle.

To determine if cells which had exited the cell cycle had a requirement for proteasome function in survival, annexin $\mathrm{V}$ staining was performed on KIM-2 cells which had been differentiated for 12 days with lactogenic hormones and were thus no longer actively dividing. Death was seen to occur at very low levels in these differentiated cells (Figure $3 c)$. This result would suggest that cell proliferation is a major component of sensitivity to proteasome inhibition.

\section{T-antigen expression abrogates proteasome inhibition induced apoptosis}

KIM-2 cells were originally generated using SV40 T-antigen (Tag) as the immortalising agent. At $33^{\circ} \mathrm{C}$, Tag complexes with $\mathrm{p} 53$, the retinoblastoma gene product $(\mathrm{Rb})$, and another $\mathrm{pRb}$ family member $\mathrm{p} 107$ resulting in a cell population with no functional p53 or pRb. ${ }^{12}$ To address whether any of these Tag binding proteins were involved in the apoptotic cascade induced by proteasome inhibition KIM-2 cells were cultured at the permissive temperature of $33^{\circ} \mathrm{C}$ and the response of these cells to MG132 compared to cells cultured at $37^{\circ} \mathrm{C}$. $\mathrm{KIM}-2$ cells were routinely cultured at $37^{\circ} \mathrm{C}$, which represents a semi-permissive state and cells switched to $33^{\circ} \mathrm{C}$ were passaged for 14 days prior to treatment. At 33 and $37^{\circ} \mathrm{C}$, MG132 treatment was continued for up to $96 \mathrm{~h}$ and the cells analyzed for apoptosis by annexin $\mathrm{V}$ expression (Figure $4 \mathrm{a}$ ). These results showed that both groups of cells were induced to undergo apoptosis following serum and growth factor withdrawal but only the cells at $37^{\circ} \mathrm{C}$ induced an apoptotic response following MG132 treatment. The difference in response observed between the two groups of cells cannot be due to the change in temperature alone and are assumed to be due to the sequestration of a Tag binding protein. Examination of the results from serum and growth factor starvation show that the rate of apoptosis induced by this stimulus was similar in both groups of cells after $48 \mathrm{~h}$ arguing against a slower rate of cell death in cells cultured at the lower temperature. $\mathrm{KIM}-2$ cells cultured at $33^{\circ} \mathrm{C}$ increased in number over the $96 \mathrm{~h}$ treatment period suggesting that these cells are actively dividing and the lack of apoptosis following MG132 treatment was not a function of exit from the cell cycle. These results suggest a role for a Tag binding protein in the apoptotic response induced by proteasome inhibition.

Overexpression of p53 is sufficient to induce apoptosis in response to a range of cell insults. ${ }^{13}$ It was assumed that p53 levels may have been elevated in KIM-2 cells following proteasome inhibition as this protein is also documented to be a substrate of the $26 \mathrm{~S}$ proteasome. ${ }^{14}$ An elevation in p53 protein alone could represent the apoptotic signal following MG132 treatment. We therefore examined the level of p53 protein in cells treated with MG132. At $24 \mathrm{~h}$ the levels of p53 protein are similar in control cells to cells treated with MG132, suggesting that there is no long-term accumulation of p53 in KIM-2 cells (Figure $4 \mathrm{~b}$ ). This result suggests that KIM-2 mammary epithelial cells are not undergoing apoptosis as a consequence of the perturbation of p53 expression.

Recent evidence has suggested a role for the proteasome in regulating the p53-responsive genes MdM2 and $\mathrm{Bax}^{15}$ To determine if these proteins were stabilised in KIM-2 cells following proteasome inhibition we examined their levels following Lactacystin treatment. Levels of p53, MdM2, and Bax did not accumulate following inhibition of proteasome function (Figure 4c). We also analyzed MdM2 and Bax protein levels in $\mathrm{HC} 11$ cells, which carry a mutant p53 allele ${ }^{16}$ to determine if stabilisation of these proteins could occur in the absence of p53. Bax and MdM2 levels in $\mathrm{HC} 11$ cells were at the limits of detection (data not shown) and again did not appear to accumulate following proteasome inhibition. These results suggest that the $26 \mathrm{~S}$ proteasome, in this system, does not influence the turnover of two downstream targets of p53.

\section{Wild-type p53 is required for apoptosis induced by proteasome inhibition}

To test the hypothesis that p53 function was essential for apoptosis induced by proteasome inhibition we obtained ES cells which contained wild-type p53 (E14 cells), and which were null for p53 (R72D27 cells). ${ }^{15}$ ES cells were treated with three different concentrations of MG132 for up to $48 \mathrm{~h}$ and assayed for cell death and cell cycle status. The levels of apoptosis were greatly enhanced in the p53 wt cells as 
(a)
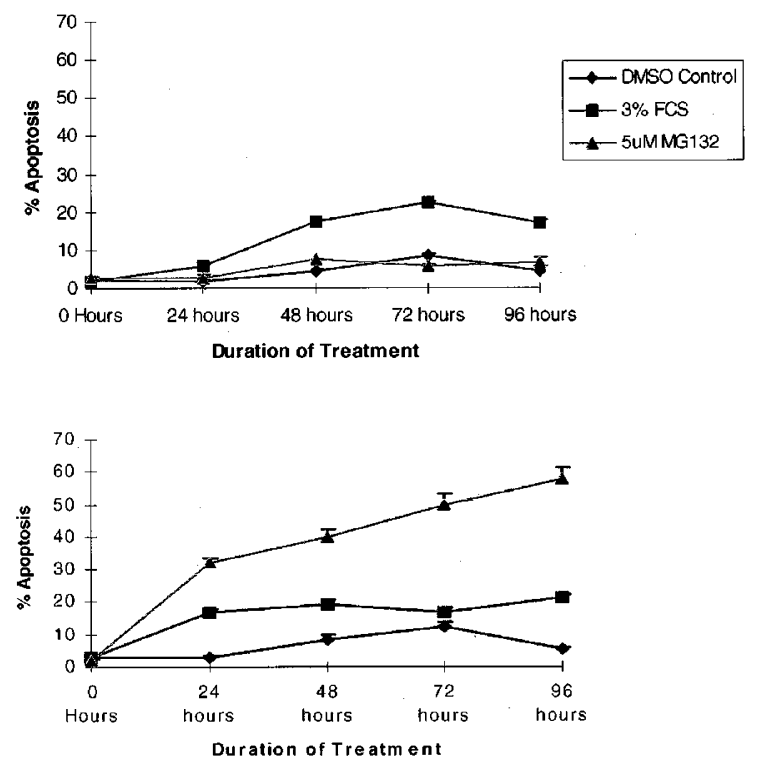

(b)

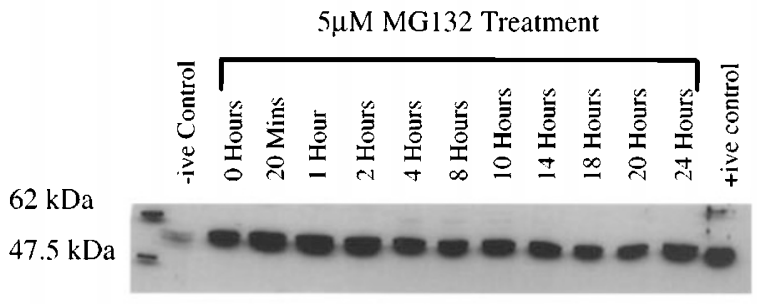

(c)

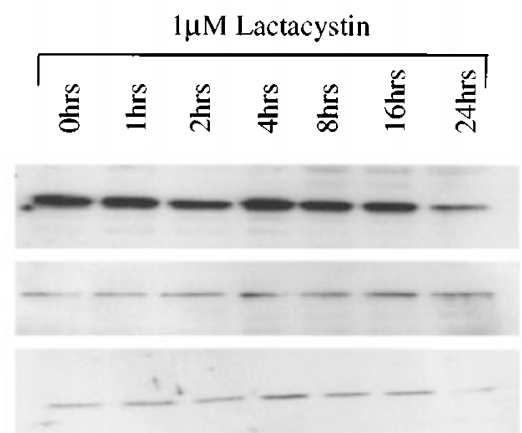

MdM2

Bax

Figure 4 (a) A role for a Tag binding protein in apoptosis induced by proteasome inhibition. KIM-2 cells were cultured at either $33^{\circ} \mathrm{C}$ (upper panel) or $37^{\circ} \mathrm{C}$ (lower panel) and treated with either DMSO, serum and growth factor

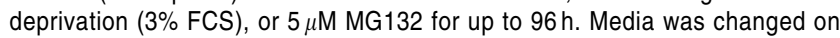
the samples at $72 \mathrm{~h}$ and replaced with fresh inhibitor, thus the $96 \mathrm{~h}$ samples represent any additional death from $72 \mathrm{~h}$. Cells were harvested and an Annexin $V$ assay performed. The data shown is the mean of three independent experiments \pm S.E.M. (b) Effect of proteasome inhibition on p53 levels in KIM2 cells. KIM-2 cells were grown to confluency and treated over a $24 \mathrm{~h}$ period with $5 \mu \mathrm{M}$ MG132 and whole cell extracts were subsequently prepared. Ten $\mu \mathrm{g}$ protein was subjected to SDS-PAGE analysis and Western blotting followed using a monoclonal p53 antibody. The -ive control is represented by $10 \mu \mathrm{g}$ protein from KIM-2 cells which had been differentiated prior to harvesting, and the +ive controls are KIM-2 cells treated with $10 \mathrm{~J} / \mathrm{cm}^{2}$ of UV irradiation. (c) Effect of proteasome inhibition on p53, MdM2, and Bax levels in KIM-2 cells. $\mathrm{KIM}-2$ cells were grown to confluency and treated over a $24 \mathrm{~h}$ period with $1 \mu \mathrm{M}$ Lactacystin. Whole cell extracts were subsequently prepared and $10 \mu \mathrm{g}$ protein subjected to SDS-PAGE analysis. Western blotting was performed using a p53, MdM2 and Bax antibodies compared to the p53 null cells (Figure 5a). Cell cycle analysis identified a G2/M block in both the cell types in contrast to cell death, which was observed only in the p53 wt cells. At higher concentrations this cell cycle blockage was accompanied with the appearance of a pre-G1 DNA peak in the wt p53 cells e.g. $3 \%$ in the control cells, which increased to $31 \%$ with $10 \mu \mathrm{M}$ MG132 treatment. In contrast the p53 null cells remained blocked in G2/M with very little death observed e.g. $13 \%$ pre-G1 staining cells for $10 \mu \mathrm{M}$ MG132 treatment (Table 3 ). These results are consistent with a requirement for p53 in the apoptotic response induced by proteasome inhibition.

To determine if the effects on proteasome inhibition were specific to KIM-2 mammary epithelial cells we examined proteasome blockage in a second mammary epithelial cell line, HC11. In contrast to the KIM-2 data, HC11 cells were not induced to undergo apoptosis with MG132 treatment. These cells were treated at concentrations of up to $100 \mu \mathrm{M}$ for $48 \mathrm{~h}$, and no cell death was observed. Additionally Lactacystin treatment also failed to induce apoptosis in $\mathrm{HC} 11$ cells. The apoptotic response induced in KIM-2 cells may have been specific to these cells and to address this question Jurkat $T$ cells were treated with MG132 (Figure 5b). Results showed a very similar effect to that in mammary epithelial cells, the contrast being that the level of death was greatly enhanced in the Jurkat cells (>80\%). Western analysis showed that MG132 was having the effect of blocking protein degradation in HC11 mammary epithelial cells despite the fact that no apoptosis was observed. Increased ubiquitinated proteins were observed in the samples treated with MG132 (Figure 5c). The results observed in HC11 may be explained due to a mutation in p53 in this cell line ${ }^{16}$ and add further evidence for a role of p53 in this apoptotic pathway.

\section{Discussion}

The results of the present study demonstrate that compounds capable of interfering with proteasome function induce apoptosis. KIM-2 mammary epithelial cells were incubated with inhibitors of the chymotrypsin-like function of the proteasome as well as with unrelated protease inhibitors. All of the three inhibitors that were capable of inducing cell death, MG132, Lactacystin and Calpain II Inhibitor, have been attributed with a function of perturbing the $26 \mathrm{~S}$ proteasome and its degradation pathway. Of these peptides MG132 and

Table 3 Induction of a G2/Mitosis arrest in ES cells by proteasome inhibition

\begin{tabular}{|c|c|c|c|c|c|c|c|c|}
\hline \multirow{3}{*}{$\begin{array}{l}\text { Treatment } \\
(24 \mathrm{~h})\end{array}$} & \multicolumn{4}{|c|}{ p53 wt ES cells } & \multicolumn{4}{|c|}{ p53 null ES cells } \\
\hline & re-G1 & G1 & $\mathbf{S}$ & G2/M & re-G1 & G1 & $\mathbf{S}$ & G2/M \\
\hline & \multicolumn{4}{|c|}{ ( \pm S.E.M.) } & \multicolumn{4}{|c|}{ ( \pm S.E.M.) } \\
\hline $\begin{array}{l}\text { Fontrol } \\
\text { (DMSO) }\end{array}$ & $\begin{array}{c}3 \\
(0.2)\end{array}$ & $\begin{array}{c}30 \\
(0.6)\end{array}$ & $\begin{array}{c}36 \\
(0.8)\end{array}$ & $\begin{array}{c}28 \\
(0.6)\end{array}$ & 4 & $\begin{array}{c}35 \\
(0.8)\end{array}$ & $\begin{array}{c}28 \\
(0.6)\end{array}$ & $\begin{array}{c}29 \\
(0.8)\end{array}$ \\
\hline $10 \mu \mathrm{M}$ & 31 & 10 & 21 & & & & 4 & 68 \\
\hline & (U.1) & & 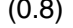 & & & & & \\
\hline
\end{tabular}

ES cells (E14 and R72D27) were treated with either 5, 10 or $25 \mu \mathrm{M}$ MG132 for 24 or 48 h. Cells were harvested and fixed in $70 \%$ Ethanol prior to staining with Propidium lodide for flow cytometric analysis. The data shown are expressed as the proportion of cells in each phase of the cell cycle 
(a)
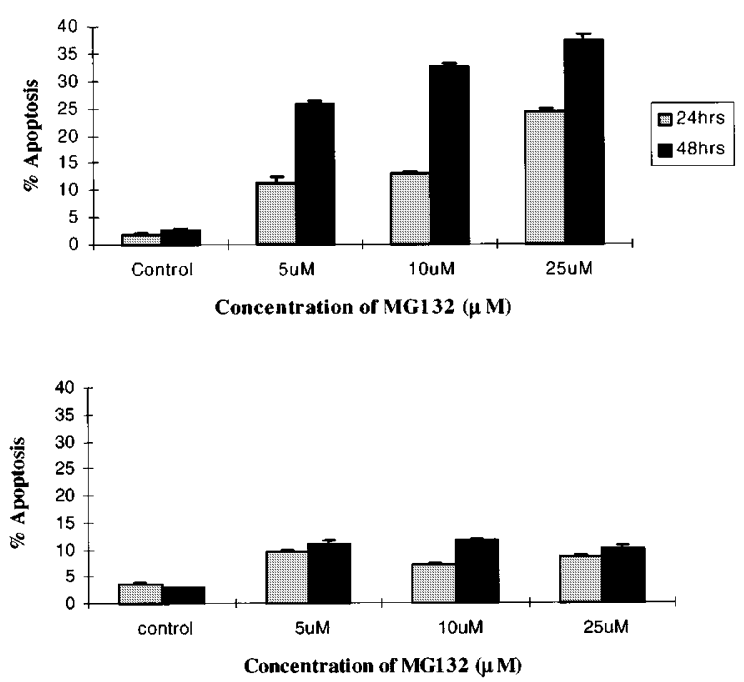

(b)

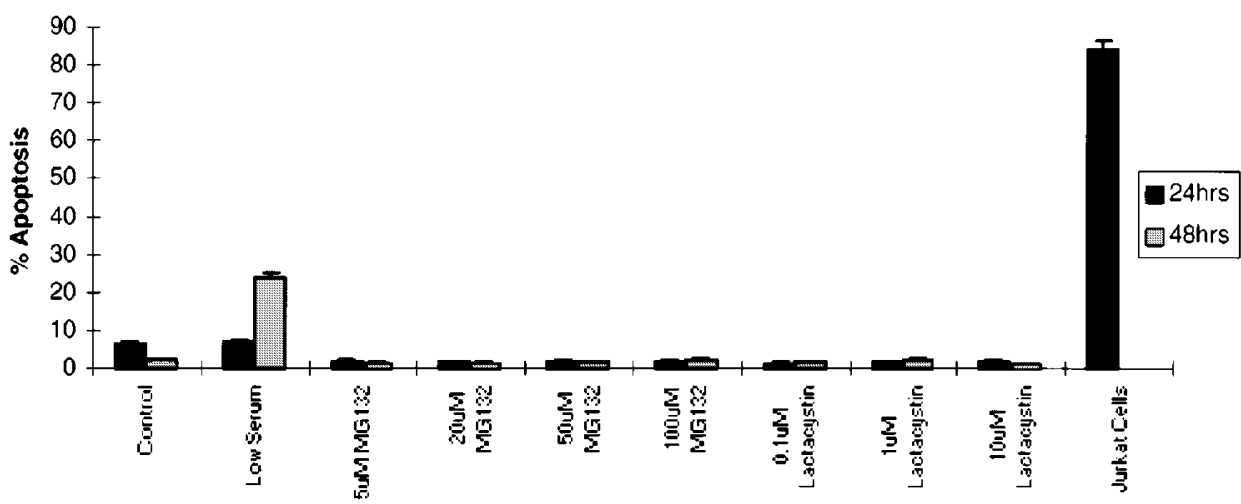

Treatment

(c)

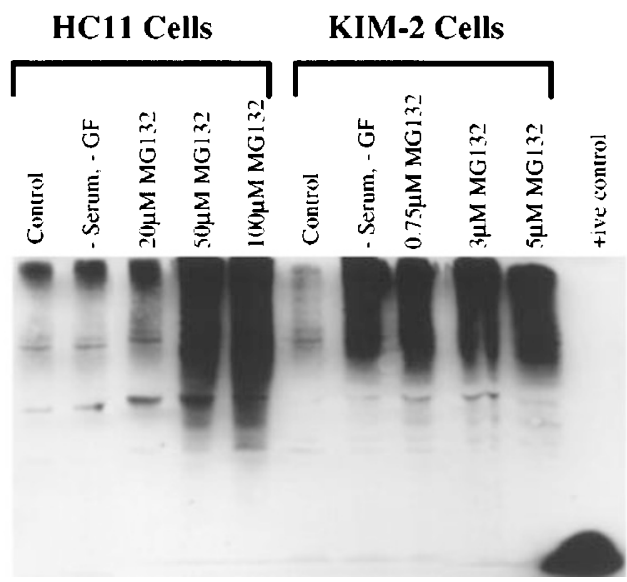

Figure 5 (a) p53 dependence on apoptosis induced by proteasome inhibition. ES cells containing wt p53 (E14 cells) (upper panel) and which were null for p53 (R72D27 cells) (lower panel) were treated with MG132 at 5, 10 and $25 \mu \mathrm{M}$ for up to $48 \mathrm{~h}$. Cells were harvested and an Annexin V assay performed. The results shown are expressed as the percentage of Annexin $V$ positive cells, and represent the mean \pm S.E.M. (b) HC11 mammary epithelial cells were harvested after 24 and $48 \mathrm{~h}$ treatment with a range of concentrations of MG132 and Lactacystin. Cells were then stained with acridine orange and subjected to a fluorescence microscopy where cell death was assessed. The data shown are means \pm S.E.M. The hatched grey bar represent Jurkat T-cells treated with $2 \mu \mathrm{M}$ MG132 for $24 \mathrm{~h}$. (c) HC11 and KIM-2 cells were incubated with various concentrations of MG132 for $24 \mathrm{~h}$ prior to protein extraction. Whole cell extracts were analyzed by Western blot for ubiquitin-conjugated proteins using a DAKO polyclonal Ubiquitin antibody. Five $\mu$ g purified ubiquitin (Sigma) was used as a positive control 
Lactacystin are the more specific inhibitors of the $26 \mathrm{~S}$ proteaseom $^{8}$ suggesting that the difference in response observed between these three inhibitors in this study is due to proteasome inhibition and not to calpain or cathepsin B inhibition. Given that MG132 had no effect on KIM-2 cells at $33^{\circ} \mathrm{C}$, the effects observed at $37^{\circ} \mathrm{C}$ cannot be attributed to non-specific cytotoxicity. These results suggest that the proteasome degradation pathway is linked to the regulation of apoptotic cell death in mammary epithelia.

A major function of the $26 \mathrm{~S}$ proteasome is the degradation of cell cycle proteins, i.e. it is responsible for the degradation of cyclins, cdks, cdk inhibitors, c-myc, p53, $\mathrm{pRb}$, and E2F. All of the above proteins are involved in cell cycle regulation and have been reported to be actively degraded at specific points during the cell cycle. In some cases, their degradation is necessary to ensure correct progression through the cell cycle. ${ }^{18}$ Therefore it seems plausible that if this pathway is perturbed then the major effects seen will be on the progression of the cell cycle. Our results agree with previous reports showing that in actively proliferating cells, proteasome function is essential for cell cycle progression. ${ }^{11,19}$ Evidence to support this theory has come from studies in Rat1 cells, which had been rendered quiescent by serum starvation. ${ }^{19}$ Proteasome inhibition failed to induce apoptosis in these quiescent cells. In contrast, both proliferating and differentiated PC12 cells could be induced to undergo apoptosis. Data conflicting with these results comes from work in neurons ${ }^{10}$ and thymocytes, ${ }^{9}$ which were seen to require proteasome function for the induction of an apoptotic response. These results can be explained by the non-proliferating status of these two cell types. Indeed, Grimm and co-workers ${ }^{9}$ have shown that in thymocytes, long term exposure to proteasome inhibitors can induce a background level of cell death. Both the thymocyte and neuron experiments suggested that the proteasome acted upstream in the apoptotic response prior to the activation of caspases. Taken together, the data available would implicate the proteasome in functioning in both cell survival and cell death pathways. Whichever pathway the cell executes may depend on its proliferative state and other cell specific factors, which remain unknown to date.

The present study also describes a dependence on p53 function for the apoptotic response to proteasome inhibition. KIM-2 cells containing SV40 Tag at the semipermissive temperature of $37^{\circ} \mathrm{C}$ underwent $>30 \%$ apoptosis in response to proteasome inhibition, whereas at the permissive temperature of $33^{\circ} \mathrm{C}$ no induction of death was observed. Results from p53 null ES cells and HC11 cells, which are mutant for $p 53^{16}$ confirmed this result. Although p53 presence was essential for apoptosis, no stabilisation of p53 was observed following proteasome inhibition. Examination of $\mathrm{Bax}$ and MdM2, p53-responsive genes, revealed no increase of these proteins following Lactacystin treatment suggesting that there was no p53-independent regulation of Bax and MdM2 expression in this system. This also dismissed stabilisation of Bax as a potential inducer of apoptosis in KIM-2 cells. Both KIM-2 mammary epithelial cells and ES cells when treated with MG132 appeared to have difficulty traversing cell cycle checkpoints, i.e. the G1/
$\mathrm{S}$ and G2/M boundaries, although in KIM-2 cells the G1/Sphase block appeared to be more restricted by MG132 treatment. The evidence for cell cycle arrest by proteasome inhibition is currently conflicting. HeLa cells arrest in G2/ $\mathrm{M}^{20}$ identical to $\mathrm{CHO}$ cells containing an ubiquitin activating enzyme mutation. ${ }^{21}$ Yeast cells containing ubiquitin mutants also $\mathrm{G} 2 / \mathrm{M}$ arrest, ${ }^{22}$ whereas the human leukemic HL60 cells arrest in G1/S phase. ${ }^{11}$ It is possible that a G1/S-phase arrest could be induced as a result of a p53 dependent apoptotic response. p53 is linked to the G1/ S-phase checkpoint through a DNA damage pathway, but p53 can trigger apoptosis via other responses, i.e. in response to metabolic imbalance or to calcium phosphate ${ }^{13}$ and can also induce death from other stages of the cell cycle i.e. from G2/M following DNA damage induced apoptosis. $^{23}$

The difference in cell cycle arrest observed between the two cell lines used in this study and other published reports cannot be explained by the presence of Tag. SV40 Tag complexes with $\mathrm{p} 53$, and $\mathrm{pRb}$ at the permissive temperature of $33^{\circ} \mathrm{C}$. p53 is a known target of the ubiquitinproteasome pathway and thus should be stabilised following proteasome inhibition. We observed no net accumulation of p53 in $\mathrm{KIM}-2$ cells in response to proteasome inhibition. This may suggest that p53 is not degraded by the proteasome in KIM-2 cells but the interpretation is complicated by the possibility that more than one intracellular pool of p53 exists within these cells cultured at $37^{\circ} \mathrm{C}$. p53 complexed to Tag may be stabilised whilst the free p53 would be available to the degradation machinery. This may have resulted in the net effect of no observed changes in the levels of the p53 protein.

In KIM-2 cells there is a potential disruption of $p R b$ function due to the presence of SV40 Tag. pRb when complexed to Tag is unable to function in regulating the activity of the transcription factor E2F-1. E2F proteins are stabilised by binding unphosphorylated $\mathrm{Rb}$ proteins. This interaction prevents E2F-1 degradation by the $26 \mathrm{~S}$ proteasome, and thus the protein is stable at the point in the cell cycle, G1/S-phase transition, at which it is essential for regulating. ${ }^{24}$ When $\mathrm{pRb}$ is complexed to Tag, there is a loss of regulation of E2F1 activity and stability. As a consequence proteasome inhibition should result in elevated levels of E2F-1, which have been reported to promote S-phase entry followed by apoptosis. ${ }^{25}$ This consequence of proteasome inhibition may suggest that death would be induced from G1/S-phase block.

Any model proposed for apoptotic cell death induced by proteasome inhibition may be highly complex. It is well documented that the sequential expression and inactivation of a variety of gene products finitely controls the cell cycle. The 26S proteasome degradation pathway is intricately intertwined with the control mechanisms of the cell cycle. A disruption in either of these pathways will lead to the inappropriate expression of a control protein for a particular stage of the cell cycle. Should a number of cell cycle proteins be inappropriately expressed, as would be the case with proteasome inhibition, then a cell may simply choose to abort cell cycle progression and as a consequence be induced to undergo an apoptotic 
response. Death from proteasome inhibition is most likely a consequence of conflicting signals given to the cell. These are signals which the cell was not programmed to encounter simultaneously. Aberrant expression of a number of cell cycle proteins, most of which are substrates of the $26 \mathrm{~S}$ proteasome pathway, has been documented to induce apoptosis. To try to dissect the precise signal which induces the cell to enter an apoptotic pathway will be complex as the proteasome degrades many proteins that have essential functions. It is becoming more apparent that the mechanisms controlling the cell cycle and apoptosis are linked. This link may be the proteasome which, dependent on the cell type and the signal received, can determine whether a cell will proliferate or die.

\section{Materials and Methods}

\section{Cell culture and reagents}

Murine KIM-2 mammary epithelial cells were cultured in $1: 1$ Dulbecco's Modified Eagle Media (DMEM) and Ham's F12 Media supplemented with $10 \%$ bovine calf serum, $5 \mu \mathrm{g} / \mathrm{ml}$ Insulin, $10 \mathrm{ng} / \mathrm{ml}$ epidermal growth factor, and $5 \mu \mathrm{g} / \mathrm{ml}$ linoleic acid. HC11 mammary epithelial cells were cultured in RPMI 1640 and supplemented with the same constituents as KIM-2 cells with the exception that $20 \mathrm{ng} / \mathrm{ml}$ of epidermal growth factor was used. ES cells were cultured in BHK (Glasgow MEM) media supplemented with $0.1 \mathrm{mM}$ non-essential amino acids, $1 \mathrm{mM}$ sodium pyruvate, $5 \%$ foetal calf serum, $5 \%$ newborn calf serum, $0.1 \mathrm{mM} \beta$-mercaptoethanol, and murine LIF. To serum and growth factor deprive cells, KIM-2 cells were incubated in DMEM-F12 containing $3 \%$ calf serum, whereas $\mathrm{HC} 11$ cells were treated with RPMI 1640 alone.

Cbz-leucinyl-leucinyl-leucinal (MG132), Ac-Leucinyl-leucinylmethional (ALLM), trans-epoxysuccinyl-L-leucylamido-3-methyl-butane ethyl ester (E64), leupeptin, pepstatin and phenylmethylsulphonyl fluoride (PMSF) were purchased from Sigma. Lactacystin was purchased from Calbiochem. MG132 and Lactacystin were diluted in $\mathrm{Me}_{2} \mathrm{SO}$, ALLM was diluted in Ethanol, Pepstatin and PMSF were diluted in methanol, and the remainder of the compounds were water soluble.

\section{Characterisation of apoptosis}

Cells were treated with protease inhibitors or dilutant alone. Supernatant and monolayer cells were harvested by centrifugation and fixed in $70 \%$ ethanol in PBS for staining with acridine orange. Equal volumes of cells and acridine orange $(5 \mathrm{mg} / \mathrm{ml}$ in PBS) were mixed on a microscope slide and examined by fluorescence microscopy. For annexin $\mathrm{V}$ analysis, cells were harvested by centrifugation and $10^{5}$ cells were stained with annexin $\mathrm{V}$ and propidium iodide using an R\&D Systems Apoptosis Detection Kit as per manufacturer's instructions. For cell cycle analysis, $1 \times 10^{6}$ fixed cells were rehydrated in PBS at room temperature for $10 \mathrm{~min}$, followed by staining with propidium iodide $(5 \mathrm{mg} / \mathrm{ml})$. All samples were analyzed using a Coulter Epics XL flow cytometer.

\section{Western blot analysis}

Cell lysates $(10 \mu \mathrm{g})$ were electrophoresed in SDS-polyacrylamide gels and transferred onto either nitro-cellulose or PVDF membranes.
Primary antibodies against ubiquitin were purchased from DAKO, MdM2 (SMP-14) from Santa Cruz, Bax (Ab-1) from Calbiochem, and p53 (pAb240) was kindly received from Prof. David Lane (Dundee). Secondary antibodies and detection reagents $(E C L)$ were purchased from Amersham.

\section{References}

1. Hilt W and Wolf DH (1996) Proteasomes: destruction as a programme. Trends Biochem. Sci. 21: $96-102$

2. Deveraux Q, Ustrell V, Pickart C and Hochstrasser M (1994) A 26 S protease subunit that binds ubiquitin conjugates. J. Biol. Chem. 269: 7059-7061

3. Chen Z, Hagler J, Palombella VJ, Melandri F, Scherer D, Ballard D and Maniatis T (1995) Signal induced site specific phosphorylation target of $\mid \kappa B \alpha$ to the ubiquitinproteasome pathway. Genes Dev. 9: 1586-1597

4. Glotzer M, Murray AW and Kirschner MW (1991) Cyclin is degraded by the ubiquitin pathway. Nature 349: $132-138$

5. Wyllie AH, Kerr JFR and Currie AR (1980) Cell death: the significance of apoptosis. Int. Rev. Cytol., 68, 251-306

6. Yuan J-Y, Shaham S, Ledoux S, Ellis HM and Horvitz HR (1993) The C. elegans death gene ced-3 encodes a protein similar to mammalian interleukin-1 $\beta$ converting enzyme. Cell 75: 641-652

7. Gordon KE, Binas B, Chapman RS, Kurian KM, Clarkson RWE, Clark AJ, Lane $\mathrm{EB}$ and Watson $\mathrm{CJ}$ (2000) A novel cell culture model for studying differentiation and apoptosis in the mouse mammary gland. Breast Cancer Res. 2: 222-235

8. Rock KL, Gramm C, Rothstein L, Clark K, Stein R, Dick L, Hwang D and Golberg AL (1994) Inhibitors of the proteasome block the degradation of most cell proteins and the generation of peptides presented on MHC Class I molecules. Cell 78: $761-771$

9. Grimm LM, Goldberg AL, Poirier GG, Schwartz LM and Osborne BA (1996) Proteasomes play an essential role in thymocyte apoptosis. EMBO J. 15: 38353544

10. Sadoul R, Fernandez P-A, Quiquerez A-L, Martinou I, Maki M, Schroter M, Becherer JD, Irmler M, Tschopp J and Martinou J-C (1996) Involvement of the proteasome in the programmed cell death of NGF-deprived sympathetic neurons. EMBO J. 15: 3845-3852

11. Drexler HCA (1997) Activation of the cell death program by inhibition of proteasome function. Proc. Nat. Acad. Sci. USA 94: 855-860

12. Schreier A and Gruber J (1990) Viral T-antigen interactions with cellular protooncogenes and anti-oncogene products. J. Natl. Cancer Inst. 582: 354-360

13. Evan Gl, Brown L, Whyte Mand Harrington E (1995) Apoptosis and the cell cycle. Curr. Opin. Cell Biol. 7: 825-834

14. Scheffner M, Werness BA, Huibregtse JM, Levine AJ and Howley PM (1990) The E6 oncoprotein encoded by human papillomaviruses types 16 and 18 promotes the degradation of $p 53$. Cell 63: $1129-1136$

15. Chang Y-C, Lee Y-S, Tejima T, Tanaka K, Omura S, Heintz NH, Mitsui Y and Magae J (1998) mdm2 and bax, Downstream mediators of the p53 Response, Are degraded by the Ubiquitin-Proteasome Pathway. Cell Growth Differ. 9: 7984

16. Merlo GR, Basolo F, Fiore L, Duboc L and Haynes NE (1995) p53-dependentand p53-independent activation of apoptosis in mammary epithelial cells reveals a survival function for EGF and insulin. J. Cell Biol. 128: 1185-1196

17. Corbet SW, Clark AR, Gledhill S and Wyllie AH (1999) p53-dependent and independent links between DNA damage, apoptosis and mutation frequency in ES cells. Oncogene 18: 1537-1544

18. Nurse P (1994) Ordering S-phase and M-phase in the cell cycle. Cell 79: 547 550

19. Lopes UG, Erhardt P, Yao R and Cooper GM (1997) p53-dependent induction of apoptosis by proteasome inhibitors. J. Biol. Chem. 272: 12893-12896

20. Wojcik C, Schroeter D, Stoehr M, Wilk S and Paweletz N (1996) An inhibitor of the chymotrypsin-like activity of the multicatalytic proteinase complex (20S proteasome) induces arrest in G2-phase and metaphase in HeLa cells. Eur. J. Cell Biol. 70: 172-178

21. Kulka RG, Raboy B, Schuster R, Parag HA, Diamond G, Ciechanover A and Marcus M (1998) A chinese hamster cell cycle mutant arrested at G2 phase has a temperature-sensitive ubiquitin-activating enzyme. J. Biol. Chem. 263: 15726 15731 
22. Finley D, Sadis S, Monia BP, BouchetP, EckerDJ, Crooke ST and Chau V (1994) Inhibition of proteolysis and cell cycle progression in a multiubiquitinationdeficient yeast mutant. Mol. Cell Biol. 14: 5501-5509

23. Guillouf C, Krishnaraju K, Moustachhi E, Hoffman B and Liebermann DA (1995) p53 involvement in control of G2 exit of the cell cycle: role in DNA damageinduced apoptosis. Oncogene 10: 2263-2270
24. Hoffman F, Martelli F, Livingston DM and Wang Z (1996) The retinoblastoma gene product protect E2F-1 from degradation by the ubiquitin proteasome pathway. Genes Dev. 10: 2949-2959

25. Johnson DG, Schwarz JK, Cress WD and Nevins JR (1993) Expression of transcription factor E2F1 induces quiescent cells to enter S-phase. Nature 365: $349-352$ 